\title{
DOCUMENTING THE UNDOCUMENTED: LIFE NARRATIVES OF UNAUTHORIZED IMMIGRANTS
}

\author{
MARTA CAMINERO-SANTANGELO
}

Although Arizona's now-notorious anti-immigration bill SB 1070 and the plethora of copycat legislation bills in several other states, ${ }^{1}$ as well as the recent failures to pass any form of the DREAM Act at a national level, ${ }^{2}$ have kept a spotlight on issues of undocumented immigration in national debates, the voices of the undocumented themselves have onlyly begun to register in this scene. ${ }^{3}$ Indeed, it is arguable that there is no population more silenced in the face of debates that most directly affect them than the undocumented. As journalist David Bacon has observed in Illegal People, "Those who live with globalization's consequences are not at the table, and their voices are generally excluded" (viii). In his introduction to Underground America: Narratives of Undocumented Lives, editor Peter Orner echoes these concerns: "We hear a lot about these people in the media. We hear they are responsible for crime. We hear they take our jobs, our benefits. We hear they refuse to speak English. But how often do we hear from them?" (7). To speak and be heard, in ways that will not immediately invite the most serious of repercussions (e.g., detention and deportation), is a challenge that unauthorized immigrants face in ways that other populations with a direct stake in US legislative battles do not. Yet, personal stories - oral history, life writing, "witness" testimonyplay an important, perhaps even a vital role in advocacy and human rights struggles, as a body of scholarship of the last decade suggests (e.g., Schaffer and Smith; Dawes; Nance; Beverley). Thus the question of how undocumented stories might participate in the public sphere where immigration policy and legislation are debated becomes increasingly urgent.

In this essay, I consider Orner's oral history collection Underground America, a rhetorically fascinating, multi-voiced text that purports to make 
hearable the voices of the undocumented and to insert these voices into the landscape of political debate. Among published accounts by undocumented immigrants, Underground America is unprecedented in its scope (it includes accounts by twenty-four immigrants of various national origins), its explicit "human rights" agenda, and its high profile and reach-published by McSweeney's as part of the Voice of Witness series founded and edited by human rights scholar Lola Vollen and by Dave Eggers, a prominent author whose other narratives of human rights crisis include What is the What (about Southern Sudan and the "Lost Boys") and Zeitoun (about civil rights in the aftermath of Hurricane Katrina). Luis Alberto Urrea, a prominent MexicanAmerican author of fiction and non-fiction, including several texts dealing with the border region, penned the Foreword. The collection has been reviewed by the likes of NPR and Publishers Weekly. ${ }^{4}$ Thus, more than any other published work to date, Underground America attempts a public hearing by mainstream audiences of the personal stories of the undocumented.

In so doing, the collection takes up a Latin American tradition known as "testimonio," referring to texts of life history meant to call attention, via the personal (but representative) story, to a situation of grave humanitarian crisis, and to charge Western readerships with the ethical responsibility of responding to that crisis. Testimonio has always faced the problem of constructing a sense of connection across the boundaries of national identity, such that readers would come to feel a sense of obligation and responsibility for what was happening "elsewhere." But this problem takes on new and complicated dimensions when the elsewhere is here-when the national "others" who are speaking are within the political boundaries of the intended readership's nation-state, yet regarded as not belonging there. ${ }^{5}$ While the potential power of testimonio resides in the ability of the personal story to construct empathy and identification in readers - and therefore testimonio needs insistently to anticipate the response of its imagined readership and to craft narrative strategies that will elicit the desired sense of ethical responsibility (see Nance, especially 50-59, 72-79) — the peculiar status of the undocumented as perceived interlopers in the "nation" creates particular obstacles to the soliciting of readerly empathy.

Mae Ngai has prominently labeled undocumented immigrants "impossible subjects," a nomenclature which signals, precisely, their positioning as categorical entities literally without status — as "non-entities" —within the logic of the nation-state. In an extension of this logic, Monisha Das Gupta terms immigrant activists "unruly' in view of their struggle for rights in the face of their formal/legal and popular codification as noncitizens"; the activists "provoke us to question the monopoly of citizenship on rights" (4). The 
undocumented immigrants whose stories are told in Underground America similarly are challenging the "monopoly of citizenship on rights" and insisting on alternative notions of rights that do not stem from codified notions of national membership. Nonetheless, the pressure exerted on the text as a whole by the circulation of vitriolic rhetoric about so-called "illegal" immigrants results in an ambivalent product in which reliance on human rights rhetoric coexists (sometimes uneasily) with notions of rights precisely based on national membership, and which ends up challenging not so much the idea that rights stem from national belonging as the idea that the undocumented narrators must be excluded from such notions of national belonging. The narrative of nation is rewritten, then, but notions of the rootedness of rights in nation are precariously maintained. The particular dilemma faced by the compilers and narrators of Underground America concerns how to solicit recognition and identification for the undocumented based upon claims of a common humanity, when such claims are inherently circumscribed by the limits placed on national belonging.

As I will discuss shortly, concepts of human rights have always been linked with notions of nation, even as they seemed overtly intended to stretch the limits of "rights" beyond national boundaries. Discourses of human rights and of national belonging have a fundamentally fraught relationship, relying on each other even as they seem to pull in opposite directions. Underground America displays a profound awareness of the imbrication of "human rights" with the construction of nationhood, and accordingly constructs an argument in which the undocumented should be "recognized" as fellow human beings precisely because they are part and parcel of a national narrative. The collection advances the premise that the immigrants it represents are already part of the "American nation," not only physically but in the more profound sense of collective belonging and participation in a national project; and that their claim to buman rights ought therefore to be recognized on the grounds of national belonging. The text, that is, appears strategically shaped to anticipate and counter the unhearability of unauthorized immigrants for US citizens and the potential inability of the latter to "recognize" the former as human beings with rights, precisely because they are "impossible subjects," inside and yet outside the boundaries of the nation-state. As I will suggest in the final portion of the essay, to the degree that the rhetorical capacity of testimonios to invite identification with the subaltern narrator is ultimately limited, we might need to consider the possibility of an ethics of responsibility that depends less entirely on identification and empathy, and that requires, instead, "recognition" of one's own participation in a larger system of privileges and inequalities. 


\section{NON-CITIZENS, NATION, AND VOICE: THE QUESTION OF SUBALTERN SPEECH}

In a substantial revision of her earlier work on public sphere theory, Nancy Fraser has recently argued that traditional formulations of the public spherethat metaphorical space in which matters of the social and political good are debated and "public opinion" is derived-have invariably taken for granted that "citizenship set the legitimate bounds of inclusion [in public deliberations], effectively equating those affected with the members of an established polity" (94). The non-citizen has no voice recognizable in the public sphere, as currently conceived, to participate in arguments about matters most pertinent to his or her own well-being, such as immigration policy and enforcement, possible routes to legal status, and so on (4-5). Peter Nyers turns his attention to the "acts of agency" involved when non-citizens do, in fact, insert their voices into debates directly impacting them and thus challenge their exclusion from a particular nation-state; he terms such practices "abject cosmopolitanism" $(415,417)$. In insisting upon their "right" to speak on issues directly affecting them, undocumented migrants refuse their construction as "abject" by dominant discourses that relegate them to the position of silenced other, and in effect reimagine the very terms of "citizenship" and "nation." We can understand Underground America as just such a manifestation of "abject cosmopolitanism" on the part of the undocumented, a refusal to accept the terms of "nation" which consign them to silence.

But such an understanding must come with qualifiers, as Nyers suggests through his probing questions: "Can the endangered speak for themselves? ... For their agency to be recognized as legitimate and heard as political, does it require mediation from other citizen groups?" (415). We cannot assume that because the abject refuse their abjection they are therefore "speaking for themselves" in some pure form. In this regard, a few preliminary words are in order on the precise nature of the "voices" that are represented in a text such as Underground America. We do well to recall that testimonio (and I am including Underground America under this genre, understood broadly ${ }^{6}$ ) is, almost by definition, a composite product, a combination of many agents shaping the final form: editors, publishers, translators, and "testifying" narrators. If testimonio provides a platform by which the subaltern can indeed speak, the very condition of subalternity requires mediation, by those with access to publishing and media venues, in order to be made hearable. It is thus a highly mediated artifact, even if, as renowned testimonio scholar John Beverley suggests, it is one that can be regarded as a form of "solidarity" (36) — or as Dave Eggers describes it, as a "partnership" between interviewees and interviewers, editors, and publishers (Gidley). And while Beverley insists that "control of 
representation [in the production of testimonio] does not flow only one way" $(38)^{7}$ - that is, only "downward" from the editor or interlocutor-the mediated relationship also of necessity bears the marks of the tension of a relationship of unequal power. Thus, while Underground America explicitly foregrounds the intent to grant hearability to the voices of the undocumented, it cannot be regarded as presenting those voices in some sort of pure essence.

It is surely a truism by now to observe that multiple contexts inevitably shape any first-person testimony; as Gillian Whitlock and Kate Douglas have put it, "the narrating 'I' is constructed historically, discursively, variously, and always with a view to the reader" (218). A considerable body of theory has challenged the premise that the pure, "authentic" subaltern voice, apart from and prior to hegemonic ideological and material forces, is somehow recoverable, or indeed, ever existed in the first place (see for instance Beverley, Spivak, Sklodowska). Untangling the "authentic" voices of the undocumented from the other forces that have shaped the final form of the text-the translations of the accounts, Orner's editing and influence, the packaging and marketing of the volume as a whole, the potential desire of the narrators to accommodate Orner's editorial direction-is thus beyond the scope of this essay, even if it were a possible (and desirable) task. ${ }^{8} \mathrm{I}$ accept, then, the impurity of the final product, and seek to consider the narrative strategy advanced by the compilation as a whole, as a mediated, composite text with multiple "authors" shaping its ultimate form-one in which the impulse to advocate an "ethics of recognition" based on universal, shared humanity sits uneasily with the perhaps more pragmatic impulse to weave a narrative of national belonging in order to enable that recognition.

\section{TESTIMONIO, HUMAN RIGHTS, AND EMPATHY}

Underground America's inclusion in McSweeny's Voice of Witness series is a prominent aspect of its packaging; front and back matter tell us that the series "allows those most affected by contemporary social injustice to speak for themselves," and "illustrates human rights crises through the stories of the men and women who experience them." The back cover of the volume explains that the series is dedicated to "Illuminating Human Rights Crises Through Oral History." The names of both Dave Eggers and Luis Alberto Urrea feature prominently. In other words, Underground America is packaged and prefaced, and its oral histories selected, as a contribution to the witness of "human rights crises" caused by current immigration laws and border security policies. By positioning itself in this way it urges readers to frame undocumented experiences as a "human rights" issue - to understand them in 
this light, where readers might not have before. It thus rather overtly presents itself as part of a project of what Kay Schaffer and Sidonie Smith call an "ethics of recognition," in which listeners and readers are called upon "to recognize the humanity of the teller and the justice of the claim; to take responsibility for that recognition; and to find means of redress" (3; emphasis added). In Testimonio: On the Politics of Truth, Beverley has put the fundamental call to recognition at the very heart of his definition of testimonio, the "dominant formal aspect" of which is "the voice that speaks to the reader in the form of an 'I' that demands to be recognized" (34). As E. Ann Kaplan explains, "One has to learn to take the Other's subjectivity as a starting point, not as something to be ignored or denied. It is only in this way that we can gain a public or national ethics" (123).

At bottom, of course, an ethics of recognition which asks readers or listeners to recognize the humanity of the speaker (or narrator) as a first step in asserting rights claims is fundamentally a call to empathy. Orner postulates that the mere act of reading his collection of oral histories will constitute a "walk[ing] in someone else's shoes" (26), a phrase that takes for granted the possibility of empathy, the imaginative occupation of the subject position of another who is not oneself. Scholars such as Kimberly Nance (74), John Beverley (37), and William Westerman (229) concur that the creation of identification with subaltern subjects is an essential (if not necessarily a sufficient) aspect of the social justice project of testimonio. ' That is to say, testimonio's aim of provoking ethical response in the reader is arguably inextricable from a process that begins with empathy. Indeed, Lynn Hunt has argued powerfully that the historical development of a conception of "human rights" relied precisely on growing cultural notions and practices of empathy, "the recognition that others feel and think as we do, that our inner feelings are alike in some fundamental fashion" (29).

By contrast, the absence of an ethics of recognition-the possibility that we will indeed ignore or deny the subjectivity of the Other-is marked by the "act of distancing," in which "the 'other' [is] constructed, out of what Tzvetan Todorov called the failure (or refusal) to identify the self in the other" (Ngai 133; emphasis added). Nance likewise refers to a process of "absenting" on the reader's part, which "assumes an incommensurable difference between speaker and reader, an uncrossable distance across which it is prohibitively difficult or even impossible to communicate." Nance adds that "Absenting may be facilitated by critiques that emphasize the localization of [subjects] in their own cultural and geographic contexts, to the point of isolation" (55). Whatever might be said about the dangers of an overly optimistic faith in the powers of empathy, it would appear that its opposite- 
distancing or absenting-immediately forestalls any project of engaging a responsive ethics.

\section{"THE RIGHT TO HAVE RIGHTS": HUMAN RIGHTS AND THE NATIONAL IMAGINARY}

Yet it is precisely the failure, across cultural and geographical distance, to identify the self in the other that is the threat posited by a national imaginary in which only those who are recognized as belonging to the "nation" can be heard as subjects with legitimate claims within the nation-state. Indeed, the substantial tension between the grounding of claims in the "bumanity of the teller" (Schaffer and Smith; emphasis added) and in appeals to a "national ethics" (Kaplan; emphasis added) is part of the history of "human rights" discourse itself, as Samuel Moyn has astutely argued in The Last Utopia: Human Rights in History. On the one hand, as Moyn acknowledges, the concept of "human rights" today is regarded "as a set of global political norms" that is associated, almost without question, with notions of "human universalism": "the belief that humans are all part of the same moral group . . . the same "family" $(10,13)$. On the other hand, this universalizing discourse obscures the rootedness of "human rights" in notions of national citizenship: "Far from being sources of appeal that transcended state and nation, the rights asserted in early modern political revolutions and championed thereafter were central to the construction of state and nation, and led nowhere beyond until very recently"; there is thus an "essential connection between rights and the state" (12-13). ${ }^{10}$ Ngai pertinently recalls Chief Justice Earl Warren's dissenting argument in Perez v. Brownell (1958): “Citizenship is man's basic right for it is nothing less than the right to have rights. Remove this priceless possession and there remains a stateless person, disgraced and degraded. . . He has no lawful claim to protection from any nation, and no nation may assert rights on his behalf" (qtd. in Ngai 229). While "human rights" are commonly understood today as a challenge to the moral primacy of any one state, Warren's famous dictum highlights the threat that the ability to recognize the claims of other human beings (an ethics of recognition) will-perhaps inevitably-be circumscribed by a national imaginary.

It is, arguably, for this reason that Underground America negotiates a precarious balance-via selection and editing, packaging, framing materials, as well as the content of the narrated accounts themselves-between, on the one hand, constructing an argument for the human rights of the undocumented, and on the other hand, recourse to a narrative that attempts to rewrite the boundaries of "nation" so that the undocumented are, indeed, understood to 
be a part of it (and therefore hearable, recognizable, by a US-citizen readership). The first-person accounts themselves, as well as the editorial materials, manifest this dual thrust, pulling in two ways at once: towards a re-imagined narrative of "American" belonging and toward a rejection of national boundaries as the binding parameters of ethical responsibility. Thus the rhetorical invocation of "human rights," conceived as non-territorial, exists side by side with efforts to reconsider (rewrite) resident "aliens" as "Americans" in order to facilitate an ethics of recognition that might otherwise be bounded by notions of national belonging.

Underground America can be understood as a text that attempts to contribute to creating a "common sense" understanding that immigrant rights are linked to human rights. The accounts in Underground America are selected, as Orner explicitly notes, because they "demonstrate gross human rights violations" or the "dehumanizing lack of dignity afforded to undocumented people" (15). Testimonio is of course intimately linked to the effort-through personal story-telling - to insist upon an ethics that recognizes human rights. Indeed, one of the narrators of Underground America, Abel, a Mayan immigrant from Guatemala, links his insistence on "rights" to the very act of storytelling: "Now I demand my rights. With or without papers, I feel I have the same rights. . . . Some of us are more comfortable speaking up about our rights-we know what we are entitled to. ... We speak to Americans, people who do have papers, people who work at organizations, people who can do something for us" (132). The assertion of "rights" is inextricably linked here with "speech"; that is, with storytelling and testimonio, told to an audience who "can do something for us." The specific source of those rights-in Abel's case as in others-is not specified (it does not come from "papers"), suggesting that, in this instance at least, he sees them as human rights, linked with personhood (rather than as citizenship rights). He thus participates in the naturalization of a notion of human rights as both universal and pre-given, rather than bestowed by a nation-state. When undocumented narrators tell stories in which they insist on their rights, they participate in the reification of those rights as a "thing" outside of human construction. Nonetheless, Abel also recognizes that in practical terms, the citizen's rights are more easily recognized and acknowledged than his own-that citizenship is understood as the "right to have rights," at least in US dominant culture. Thus he is willing to seek help from citizens to secure his own (unacknowledged) rights.

When questioned by US Immigrations and Custom Enforcement (ICE), Diana, another narrator, also invokes her rights. "But I knew my rights from the meetings," she recalls, "I need my lawyer. I have a right to a lawyer, I have the right to make a phone call"' (26). Diana's account insists on her own 
status as a legal subject with "rights," and demands an ethics of recognition, even though it is not forthcoming-part of the story is about the way her rights have been violated. Her lawyer, for instance, never "found" her in the New Orleans holding cell to which she was consigned when she was detained (26-27). Perhaps more strikingly still, Diana's account, like Abel's, recognizes the currency of stories in the struggle over "rights." ICE "wanted everyone's story" but Diana "knew I didn't have to tell them" (26). While ICE would use Diana's account of her country of origin and of her undocumented status as a story that "proves" her unbelonging — and thus deport her-Diana withholds that story from them, yielding it, instead, to us, as a testimony, a story of the refusal of ethical recognition based on human rights. Thus, embedded in her own account is a faith in the power of stories as a means to move others. At the same time, Diana's account suggests an awareness (if only after the fact) of the ways in which stories of testimony like her own might be ignored: "A few times I told the others that we have to report this. They told me to be quiet. 'But we're here in this county where human rights are respected,' I said. One woman said, 'Who told you that? Those are just stories"' (28). Diana's own words contain, in miniature, the tension between human rights understood as universal and their potential boundedness by nation and national belonging ("in this country"). If you are "in this country" but are not recognized as belonging here, are your human rights respected? Will your story be heard? Will you, indeed, be recognized as a human being with the "right" to tell a story that will be recognized as having some claim on other human beings? Echoing James Dawes's overriding concern, in Bearing Witness to Atrocity, with the ways that "stories designed to shake us out of our self-absorption and apathy can fail" (10), Diana here betrays a grave concern with the possibility that her testimony might itself be "just" a story, stripped of its political value as testimony, because she is not hearable "in this country."

At the opposite end of the spectrum from Abel and Diana, who insist on their "rights" and on the value and import of their stories, is a narrator referred to in the text only as "El Mojado" (the wetback). Accepting this derogatory pseudonym with its emphasis on non-belonging, the narrator arguably participates in his own continuing erasure of self as an unauthorized national presence. El Mojado emphasizes his profound sense that he has no rights (as a non-citizen), and therefore does not feel recognized as a person: "I can't fight for my rights. I have no rights here in the United States. I don't have a right to anything, I can't fight anything. I know I'm nobody important" (210). El Mojado displays a sophisticated understanding that rights come with, and are ensured by, citizenship; in the absence of citizenship, El Mojado feels, quite pragmatically, that he has no rights (because the nation-state will not 
guarantee them). He is "a stateless person, disgraced and degraded" (Warren, qtd. in Ngai 229) — in our modern era, barely a person at all. In contrast to El Mojado's lament, Abel's and Diana's stories about speaking up for their rights constitute a direct counter-narrative to forms of discourse that deny rights based on the lack of citizenship: Abel challenges the claim of another that, "according to him, I didn't have a single right, nothing" (127), which is tantamount to saying that he is not human.

Nonetheless, it would seem that El Mojado's anxiety about non-recognition based on the boundaries of nationhood might win the day; at the very least, such anxieties exert a considerable force on the structure of the overall narrative. In his introduction, Peter Orner, who is a former lawyer, describes presenting the asylum case of a Guatemalan immigrant, "Eduardo," in court, only to have the case denied. As Orner tells it, the government counsel suggested informally afterwards that perhaps "the judge might have just simply seen one too many Guatemalans that day." Orner takes this incident as a jumping off point for a meditation on the ethics of recognition:

One too many Guatemalans. Over the next few months those words rattled around my head. Eduardo had survived a horrific experience only to be considered one of too many. Maybe Eduardo's essential problem was his very existence. His presence alone seemed to have pushed the judge over some imaginary line. . . . Afterward, I began to think about all those other people out there implied in the phrase one too many Guatemalans, which seemed to me another way of saying one too many stories. (7)

Orner's rhetoric here can be read as nothing less than an ethical rebuke to the position that would grant recognition (or withhold it) on the basis of national unbelonging. It intimately interweaves notions of hearability ("one too many stories"), and thus of fundamental humanity ("his very existence"), with the lines drawn by the category of nation itself, such that to be an alien within that category is fundamentally to lack any claim to human recognition ("his presence alone" is the problem). In this moment, the editor of Underground America displays a profound concern that any ethics of recognition-any invocation of the claims and responsibilities stemming from a common humanity_will fail, because "Guatemalans" are not "Americans." "They" are not "us."

The strategic response to such a pervasive anxiety is to make the case that they are us. Coexisting alongside of the "human rights" discourse clearly evident in the collection, the tenor of the narratives in Underground America is one in which, as I have already suggested, undocumented immigrants are part of an American (US) narrative and nation. Orner's introduction, which (along with Urrea's foreword) frames the accounts that follow and 
provides an interpretive lens by which to understand them, thus also insists that undocumented immigrants "are an integral part of this society and this economy" (12), even if not generally recognized as such. Orner explicitly reinscribes the desires, goals, and ambitions of the collection's narrators- "to keep their families safe, to make a little money"-into the classic American Dream narrative: "Is there anything more American than this?" (13). Indeed, for Orner, what is not particularly "American" is the inability of the undocumented to speak out, to speak for themselves and represent their interests, because of fear (13).

The undocumented narrators included in the collection, too, seem quite canny about the potential rhetorical power of insisting on their own "Americanness," and thus this theme sketched out by Orner is repeatedly echoed in the accounts themselves. ${ }^{11}$ Abel, for instance, is certainly aware of the rhetorical maneuvers that position immigrants as not belonging within the fabric of the nation; he makes reference to discourses in media and politics of "cleaning out immigrants" (130), as though they are pollution or trash to be disposed of. In retort, Abel insists: "I feel American-I have never felt like a Guatemalan, because I couldn't develop myself there" (132). Abel redefines what it might mean to be an "American" from a legal status to an internally defined state of belonging and identity. One becomes "American," as with so many other identities ("Feminist," "Democrat," "Republican"—even, via the mechanism of the US census, "white" or "Hispanic"), through self-identification.

The accounts of Diana and Polo, who each worked on cleanup efforts in Mississippi following Hurricane Katrina, are testimonies of the ways in which, to recall Orner's introduction, undocumented immigrants "are an integral part of this society and this economy" (12), and yet are treated as disposable, contingent. Polo recalls working for a Halliburton subsidiary cleaning up the Seabees Naval Construction Battalion Center-but never being paid, because the boss disappeared (136). In her account, Diana relates being hired, like Polo, as cheap labor to help with rebuilding after Hurricane Katrina:

When cleanup and reconstruction began there were a lot of jobs available. . . It was hard, dirty work and by the end of that first week most of the whites and blacks had quit. ... The construction people who'd offered us our jobs began to ask for more Hispanics to work on their crews: more Hispanics, more Hispanics, more Hispanics. They asked us to call people we knew to come and work, and we did.... We exposed ourselves to diseases working those construction jobs. The mosquitoes would bite us and leave enormous wounds. I still have spots on my legs from those bites and from the chemicals and insulation that came off the walls at those jobsites.

When the police passed by our construction sites they never stopped or said anything. The immigrant workers were necessary to get the work done. (24) 
Diana's story serves as a synecdoche (as all good testimonio does) of the long history in US immigration enforcement of turning a blind eye to the employment of undocumented immigrants when their labor was crucial to substantial economies (such as farming economies at harvest time), subjecting them to hazardous and substandard labor conditions that they had no power to protest or improve (pesticides, chemicals, unsanitary work and housing, insufficient drinking water, etc.), and then stepping up enforcement when the demand for labor dropped. ${ }^{12}$

Strikingly, considering the remarkable growth of transnational labor, as well as the resulting transnational affiliations and communities that are considered the hallmarks of our current condition of globalization, a transnational sensibility is relatively absent from these narratives-no doubt strategically so. Understandings of transnationalism tend to emphasize a sense of dual belonging, to two nation-states at once: Alejandro Portes, for instance, discusses the "dual lives" experienced by immigrants who "frequently maintain homes in two countries, and pursue economic, political, and cultural interests that require a simultaneous presence in both" (76). Along the same lines, Nora Hamilton and Norma Stoltz Chinchilla understand transnationalism as pointing toward a "two-way flow of people, ideas, and cultural symbols" across nation-state borders (10). "Transnationalism" has become a categorical concept with considerable currency in academic scholarship on immigration and ethnicity, but for undocumented immigrants seeking legal status in the United States, overt suggestions of dual allegiances, to host and home countries, or (perhaps even more incendiary) of repeated crossings back and forth over borders, would be rhetorically dangerous, to say the least.

Accordingly, Underground America on the whole eschews an emphasis on the act of border crossing itself. ${ }^{13}$ Such a focus, whatever else it might achieve in terms of the undermining of traditional, highly bounded notions of national allegiances and identifications, would underscore the perceived "unbelonging" of the immigrants within US territorial, nation-state boundaries - and analogously, their unbelonging in a narrative of (US) nationhood. Indeed, Ngai has argued that the act of crossing the border illicitly in the twentieth century became laden with a powerful symbolism that it had not held previously: "walking (or wading) across the border emerged as the quintessential act of illegal immigration" (89). Border crossing became synecdochic of a larger willingness to violate the law, which made Mexican border crossers undesirable entrants on purportedly moral grounds. Crossing stories in Underground America, when they are provided at all, are accordingly often drastically downplayed. Diana simply states that she "made the decision to go back to the US, this time for good," and leaves it at that (20). Roberto, Olga, 
and Abel each devote approximately one paragraph to their crossing stories, which are clearly not the heart of their accounts $(58-59,104,121)$, but only a part of a much longer testimonial narrative.

Rather than instantiating illicit border crossing as the center of the paradigmatic undocumented story, these accounts are seemingly elicited, selected, and edited with an eye to the ways in which they reinforce a narrative of national belonging - as with the example of the narratives by Diana and Polo about assisting in the cleanup efforts after Hurricane Katrina, which underscore the role of undocumented labor in the aftermath of events that have become constructed as "national" disasters. Such accounts reconfigure immigrant laborers not as transnational figures with a foot in two worlds, but as already "American" in geography, loyalties, and participation in geopolitical events; they literally write themselves into a larger, ongoing national story. So too, other narrators, such as Abel, insist not only on the economic value of their labor but on its national or symbolic value: "I've even made police uniforms, firemen's uniforms, government officials' uniforms" (131). Sewing the nation's uniforms, Abel stitches himself in a wonderfully metaphorical way into the "fabric" of the nation itself. Lorena, a young activist who was brought to the United States by her mother when she was six, mocks the presumption that recent immigrants don't "want" to assimilate or to become American; discussing California's law providing in-state tuition for undocumented students who have graduated from California high schools and met certain conditions, Lorena notes that she "had to sign an affidavit stating that ... I would get legal residency as soon as I was able to. I think that last one is for those conservatives who think we're just educating terrorists. It's pretty ludicrous. I mean, who wouldn't want to get legal residency?" (190). Roberto attempts to re-locate his children narratively into the US (since they have been forced to return to Mexico) through a counter-discourse of belonging; both his daughter, who came as an infant but was deported in the sixth grade, as well as his US citizen son, "really grew [up] here in San Francisco. They spent their whole lives here. They learned to speak English, and they did very well in school. . . . Jennifer especially-since she had spent nearly ten years here, she had become very accustomed to things here. . . . My children did not want to leave" $(71,73)$.

In one of the few accounts that devote some attention to the actual act of crossing, the emphasis is on the liminality of the border space, and the consignment of those who cross it without authorization to the margins of human recognition itself. Julio renders his experience in the desert in near-biblical terms, conveying the existential crisis of non-recognition: "I was alone. I was crying, nobody saw me. I talked, nobody heard me. . . A body nobody finds" 
(180). The anguish of not being recognized as a human being with claims is conveyed metaphorically through Julio's sense of disembodiment, of being a body that no one sees or hears. If a body is in the desert but no one knows it is there, does it exist? In a similar vein, Roberto, explaining how he had to demonstrate an unbroken record of living in the United States to support his application for "suspension of deportation," says, "I had to prove I had existed here for ten years" (72), thus converting a territorial claim about residence within the boundaries of a nation-state into an existential claim of humanity that risks being denied. Conveying his agony in the wake of his family's deportation back to Mexico while he has stayed on in the US to support them, Roberto says, "Sometimes I laugh by myself, at myself. Sometimes I talk to myself. Sometimes I cry by myself. Sometimes I scream by myself. Who am I? I'm nobody" (74). "El Mojado" echoes: "I know I'm nobody important" (210). The repeated refrains of being "nobody" underscore the speakers' visceral experiences of the ways in which the nation-state framework deniesindeed, obliterates - their claims to humanity. Because their testimonies bear witness to this erasure, they can be read on one level as a continuing refusal of the abject position to which they are consigned, even as they seem to inhabit it most thoroughly. At the same time, such textual moments of seeming existential crisis also suggest the narrators' pervasive anxiety about the potential failure of their own stories to elicit an ethics of recognition from readers.

\section{THE NATIONAL "BODY"}

In countering such anxieties, the narrators of Underground America repeatedly insist on calling attention to their own bodies, as a trope for insisting on claims both to a common humanity and-albeit more subtly-to American belonging. In Inventing Human Rights, intriguingly, Lynn Hunt connects the evolution of the concept of inalienable human rights to a context of "Greater respect for bodily integrity and clearer lines of demarcation between individual bodies" (29). Inextricably linked to the act of imaginative empathy that, according to Hunt, was necessary for notions of universal human rights to emerge, was a growing concept of bodily inviolability (82). Hence, one of the essential human rights recognized today is the right to bodily inviolability: we have the right to be protected from the intentional infliction of extreme physical pain, for instance, as well as from the violation of our bodies through rape. Article 3 of the Universal Declaration of Human Rights declares that "Everyone has the right to life, liberty and security of person," and Article 5 states that "No one shall be subjected to torture or to cruel, inhuman or degrading treatment or punishment." To see the emerging discourse of human rights as intimately tied to these developing notions of the inviolable human body is 
also to understand the ways in which discourses of the body are part of a larger rhetoric of recognition based on an assumption of common humanity: if you recognize the pain of my body, you are recognizing me as a fellow human being entitled to protection from the infliction of pain.

Roberto's testimony is striking, among other things, for how it reminds us of the ways in which the body is deeply imbricated in the condition of being an abject "illegal." He laments the profound sense of loss of his family, which has returned to Mexico, through the enigmatic phrase: "I am[;] I don't resemble anyone" (his rendering of this "old saying in Mexico" is given only in this rather awkward English translation), which he links to being "nobody" (74). Roberto metaphorizes his family's loss through the suggestion of a severing of biological, genetic connectedness - in the absence of his family members, no genetic tie causes him to "resemble" anyone. Thus the dissolving of filial and social ties (through physical separation) is conveyed biologically. Abel's story, which also describes in bodily terms the psychological trauma caused by what Orner terms a "culture of anxiety" among the undocumented (10), moves Douglass-fashion from his own case to broader generalizations:

There are still a lot of people here who have been left traumatized because their husband or their wife has been taken away. They think that every helicopter that goes by-it's Immigration hunting for them. Some of the people who were in jail [on immigration charges], they seem scarred.... They hear the wind knocking on the door. They think every sound is Immigration. So their senses are not whole anymore.

It is all about fear. Fear invades us. One is always afraid. ... It's like poison in your brain. (129-30)

As with other instances of testimonio, trauma is described in terms of psychological effects that are marked on the body - that become, that is, embodied. Fear is a "scarring," a "poison" that "invades" the brain. The body testifies materially to the trauma of an underground, undocumented existence; it counteracts that trauma by insistently reminding readers of a fundamental, shared, physical humanity.

To return to the notion of an ethics of recognition: a typical interpretation of the ways in which undocumented immigrants are "seen" (or perhaps, "misrecognized") in US popular culture is that they are reduced to the sheerly physical. Their bodies are racialized, and race is read as precisely the "sign" of their unbelonging; as Lázaro Lima notes in The Latino Body, even as far back as the Zoot Suit Riots of the 1940s (and earlier), "the Mexican body had already been represented as an interloper on the national landscape" (61). The tautology of the racial marking of Mexican bodies is that "these people are not American because they are racially different from 'real' Americans, and 
they are racially different because they are not Americans" (5); it is precisely this tautology that is at stake in outcries over Arizona's SB 1070 and other such legislation that raises charges of the potential for "racial profiling." Further, undocumented immigrants (and, in the mid twentieth century, "braceros") are identified synecdochically in terms of the strength of their bodies; the term "braceros," referring to those who benefitted from the guest worker programs of 1942-1964, and who were regarded as in many ways interchangeable with "illegal" labor, limits the person precisely to the physical body-the arm or "brazo." "Illegal" immigrants, in the national imaginary, are understood to be manual laborers. (It is perhaps worthy of note that the common Spanish name "Manuel" is, in its Anglicized form, mispronounced as a homophone of "manual.")

Nonetheless, the reduction of immigrant to physical body is a bit more complicated than this argument might suggest. Perhaps counterintuitively, the development of immigration policy and debate in the twentieth and early twenty-first centuries has increasingly, in some ways, denied the embodiment of the "illegal" immigrant, and to the degree that the body inevitably stands as a metonym for the person, thus denied the immigrant's personhood as well. Ngai argues that one of the notable shifts marked by the changes in immigration policy in 1924 was the shift from bodily inspection of immigrants (to screen for physical illnesses) to the inspection of documents. The result was that "The system shifted to a different, more abstract register, which privileged formal status over all else. It is this system that gave birth to what we today call the "undocumented immigrant"' (61). Ngai suggests that "The illegal alien that is abstractly defined is . . . a body stripped of individual personage" (61; emphasis added). I would suggest, however, that part of the stripping of personhood has to do precisely with the abstraction of the body-that is, with the dis-embodiment of the immigrant via the primacy of "documents," with their emphasis on national belonging, over physical and psychological "personage." Whereas formerly considerations that are eminently embodied-familial relations, long-standing residency within the United States, productive contribution to the US economy-weighed against the practice of deportation, as the status of documents gained importance, the immigrant's embodied enmeshedness in social relations within the US - the immigrant's personhood, as well as the particular "Americanness" of that personhood-was gradually but utterly effaced.

In response to such a dynamic, which refuses to see immigrant bodies as "signs" of personhood and to read them as belonging to a larger landscape, immigrant stories call insistent attention to the bodily trauma of being undocumented, and thus reinvest the body with its "individual personage." Undocumented immigration is, among other things, a physical condition. 
It is regularly characterized by bodily trauma (rape, dehydration, hyper- and hypothermia, injury), and it leaves its signs upon the body in other ways as well. That insistence on the body in the testimony of the undocumented, in narratives such as Abel's, can be read as a counter-narrative to the abstraction of personhood into the authority of documentation. Furthermore, as we have already begun to note, this embodiment is linked representationally to the family ties of the immigrant. Embodiment is not sheerly or reductively physical, but signals the immigrant's physical, biological, and also social and psychological imbrication within a geographically situated network of others, such that the severing of these ties (or the threat of it) is experienced bodily.

Consider, for instance, Abel's account of a friend of his who was killed in a fish-processing machine. The story deserves to be quoted at some length:

\begin{abstract}
There were very bad accidents. I remember one of them that happened about ten years ago. I was nearby when it happened. At the plant, there was a machine for grinding the meat of the dogfish. We'd clean the fish, take off the head, the fins, the tail, the meat, and the bones. And then we'd put it all in a machine to be ground up. This machine was very dangerous, and no one ever explained to us how it functioned. The temperature inside reaches 180 degrees. Once, we were told to clean it, to clear out the bones. To do this we had to climb inside. It was like being inside an oven. I felt like I was being burned. I climbed out to save myself. And this other person, my friend, who was still in the machine-he died. He died in the machine. It was absolutely horrible. He was in the U.S. with his son. I left that place after my friend's death.... (124)
\end{abstract}

Abel's narrative structure here works insistently to rehumanize the body, to invest the "bones" that are ground up in the machine with personhood. He begins by detailing the power of the machine to crush the "head, the fins, the tail, the meat, and the bones" of the fish, which are all "ground up" inside the machine. But of course the passage has begun already with the indication of a horrible accident, so readers are predisposed to connect the bones and meat of the fish to other bones and meat that, we cannot help but assume, will also be crushed. The account then goes on to put literally the human being in the place of the product (the fish) that will be ground by the machine-Abel enters the machine, where he feels as if he is being baked in an oven, and must leave to save himself. By this point, when we learn that another man is crushed within the machine, we have already been primed to consider the physicality of the experience: the crushed bones, the ovenlike heat, which renders a man into the equivalent of fish-meat. Abel, that is, insists on the body's physicality, and invites readers to imaginatively and empathetically place themselves (as he placed himself) inside the oven-like machine with the man who dies. 
But this is not the end of the account. Abel also reinserts that body (which might fairly easily have simply been abstracted into "crushed bones") into a larger social network. He was the man's "friend." The man also had a "son." Both were "in the U.S." together. (In the detailed appendix supplied by Orner, we learn that the son actually witnessed the accident that killed his father.) The accident, in fact, is so traumatic in its effects on the human relations within which Abel's friend was inserted that Abel must leave his employment with the fish-processing plant. The immigrant is decidedly a biological, physical body, but that body is part of a larger, meaningful network in which "bodies" are understood as fathers, sons, friends, co-workers-not just "bones." Embodiment, then, becomes a way in which some of the narratives reconcile claims to "American" belonging with claims to human rights. The body is above all human, but it is also emplaced, a body that exists in a particular place and has ties to that place through family, community, and social networks.

\section{THE FAILURE OF EMPATHY AND AN ETHICS OF RESPONSIBILITY}

I want to close by returning to Orner's optimistic faith that readers, being willing to imaginatively inhabit the shoes of another, might consequently be more likely to participate in an ethics of recognition-and to the repeatedly manifested fear in both his introduction and the immigrant narratives themselves that the call for such an ethics will fail. It is worth noting that, with reference to undocumented migrants, the cliché about walking in another person's shoes is sometimes invoked to summon up the specter of the failure of empathy, rather than the condition of its possibility. El Curita ("the priest"), a man held in virtual modern-day slavery in the US, insists, for instance, that "No one can know what it was really like unless they were to walk in our shoes" (176). In El Curita's understanding, walking in his shoes cannot be mere metaphor; it must be literal experience. Thus he repeatedly underscores the impossibility of full empathy in the absence of common, shared experience: "No one could really understand unless they had experienced what we had. Truly, you would have had to have lived it firsthand to know how we suffered" (176; emphasis added). Part of the problem, for El Curita, is his awareness of a lack of "proof" - a lack that is, strikingly, transposed onto the body: "We didn't have physical marks we could point to, nothing outward to show how we were being abused. But we had scars in our souls" (169).

Such comments might be read as underscoring the need for exotopy, the corollary of empathy - that is, as Nance explains in her gloss on Bakhtin 
(62-63), the ethical necessity of recognizing that identification can never be complete, precisely because the US citizen cannot fully know, emotionally, psychologically, and physically, the experience of the undocumented immigrant. ${ }^{14}$ And that recognition, too, is vital in an ethical response that would acknowledge and use the particular privilege and power of citizens to advocate on behalf of the undocumented in ways that the undocumented themselves cannot. As some research has persuasively suggested, empathy alone, it turns out, cannot constitute an adequate ethical response, given that such an ethics necessarily involves the taking of responsibility for the claims of others.

To illustrate using a related example: Sanctuary Movement citizen-participants in the 1980s often framed their involvement in terms of shared humanity with the oppressed refugees, while simultaneously pointing attention to the specific role of US foreign policy in political migration from countries such as El Salvador and Guatemala - thus invoking the responsibility of listeners, as US citizens, to address the situation they were hearing about (Cunningham 592, Coutin 69-70). Nance postulates that the ethics of our responses to the stories of other people's suffering is conditioned by a dual movement in and back, by which we

must embark on an imaginative passage beginning with identification with the sufferer but conclude with an assessment of [our] . . . own inclination and capacity to help. . . . [R] eaders must be induced to see the speaker's suffering by imagining themselves in that same situation. Those readers must then return to their own place in the world and consider the unique ways in which that position enables them to assist others. (62-63)

As Bakhtin puts it, empathy "must be followed by a return ... to my own place ... for only from this place can the other be rendered meaningful ethically" (25-26). Participants in the Sanctuary Movement were moved both by a sense of common humanity and by acknowledgment and acceptance of a particular role as citizens of a specific nation-state-a role which marked their separation and difference from the sanctuary recipients who offered their testimony.

This larger sense of an ethics of responsibility requires self-recognition in addition to recognition of the other-that is, it requires recognition of the ways in which our own positions within the nation-state framework make us potentially complicit in the forms of oppression and denial to which the stories of Underground America bear witness. Yet the text's call for a broader ethics of responsibility that would move beyond empathy is potentially flattened through the concessions to a narrative in which common humanity can be made legible only through claims to national belonging. The testimonies 
in Underground America ultimately suggest the fear that, because the (nonbodily) scars on the souls cannot be seen-because they are not readable within the context of a narrative of nation-no one will know (or care) that they are there.

\section{NOTES}

1. Since the passage of SB 1070 in April 2010, five states to date (Alabama, Georgia, Indiana, South Carolina, and Utah) have passed similar omnibus legislation (Segreto et al.). Alabama's HB 56, now hailed as the most restrictive and punitive of state antiimmigration laws, became law in June 2011. In June 2012, the US Supreme Court struck down several key provisions of SB 1070 but left standing section 2(B), the socalled "show me your papers" provision, which requires law enforcement officials to check the immigration status of people stopped or detained on other grounds if there is "reasonable suspicion" that they could be present illegally.

2. The DREAM (Development, Relief, and Education for Alien Minors) Act would provide a path to citizenship for undocumented youth who came to the US with their parents and who have attended US colleges or served in the military. In 2010, two attempts to pass the DREAM Act failed to overcome Senate filibusters.

3. Elvira Arellano, an unauthorized Mexican immigrant who took sanctuary in a Chicago church during 2006 and 2007, became perhaps the most prominent undocumented spokesperson for immigrant rights until the recent revelation that journalist Jose Antonio Vargas is undocumented. Undocumented student activists for passage of the DREAM Act have maintained a prominent web presence and have engaged in public demonstrations. In Latino letters, recent novels and non-fictional accounts have begun to integrate literary representations of the experience of undocumented immigration into a Latino/a canon (see Caminero-Santangelo, "The Lost Ones").

4. Previous efforts to collect the stories of the undocumented were far more limited in their venue and scope. The 2004 collection The Border Patrol Ate My Dust appeared first in Spanish in 2002; its editor, Spanish-language journalist and radio personality Alicia Alarcón, originally asked callers to tell their stories on the air. The main audience was thus, presumably, Spanish-speaking immigrant communities. Unlike Underground America, Border Patrol did not attempt to frame the stories it collected in any way, and did not present the accounts as part of a project of witness or advocacy. Underground Undergrads (Madera et al.) was written and compiled by undocumented students advocating for the DREAM Act; published in 2008 by the UCLA Center for Labor Research and Education, it did not have the mass market reach of McSweeney's.

5. A possible secondary readership for first-person narratives by the undocumented consists of other undocumented immigrants themselves (and their communities). These narratives contribute to what is known in liberation theology as a process of "conscientization"that is, the "process of becoming conscious of the often unjust political and social reality and its root causes" (Westerman 228) at a communal and collective level; they thus serve the potential function of constituting an activist undocumented community by motivating unauthorized immigrants themselves to agency and activism. 
6. Underground America inherits a legacy of transplanting testimonio to US contexts, as Westerman indicates in his discussion of the 1980s Sanctuary Movement (228). The defining genre characteristics of testimonio as laid out by Nance, Beverley, and others hold true for Underground America as well, albeit in a more explicitly "collective" format: it is a form of life history in which the individual voice is meant to be in some sense representative of a larger set of social conditions, for the purpose of forcing readers' awareness of these issues and of promoting ethical responses.

7. Beverley proposes an understanding of the collaborative and mutually affective nature of the relationship between narrator and compiler/editor, arguing that "Testimonio involves a sort of erasure of the function ... of the 'author" understood as an individual in complete artistic control of his or her text (35).

8. According to Orner, "The people we finally chose for [Underground America] were people who were very invested in having their story told publicly. They wanted to be heard in some way.... [E]specially when there was an egregious human rights issue involved, people really did want to get that out, because they had no other way to tell that story" (Joiner). Further, reportedly, the Voice of Witness series of oral history collections does not publish final accounts without the narrators' approval and allows them to make changes and modifications to their original testimonies later (Gidley). While that measure suggests the narrators' agency and control over their stories, it remains impossible to separate entirely the "pure" voices of the undocumented from other forces shaping their accounts.

9. Beverley proposes that "The complicity a testimonio establishes with its readers involves their identification - by engaging their sense of ethics and justice-with a popular cause normally distant, not to say alien, from their immediate experience" (37). Westerman notes that the oral narratives of refugees in the 1980s Sanctuary Movement were calculated to create "intimacy" with their audiences: "personal identification with the refugee became essential" (229). Nance warns, however, that empathy in isolation might actually be counter-productive to the goals of testimonio, and emphasizes the correlative importance of "exotopy" $(71,63)$, a point I discuss at the end of this essay. Sommer is profoundly skeptical of the ethical implications of empathy ("No Secrets" 131; "Taking a Life" 925-26).

10. See also Peutz and De Genova 7, 9.

11. Of course, it is impossible to discern how much of this effect is a product of the editing of Underground America. The narrators, for instance, might have been prompted by questions which specifically directed them to speak about the degree to which they felt "American"; the inclusion of some accounts over others might also have been guided by this thematic principle; and in any case, readers cannot help but bring to bear the framing of Orner's introduction on the testimonies contained within its covers.

12. See for instance Peutz and De Genova; De Genova; and Bacon.

13. The earlier first-person collection The Border Patrol Ate My Dust, by contrast, focuses primarily on stories about the act of migration itself, including illicit journeys back and forth across the border.

14. See also Wyatt on the appropriative tendencies that are linked with "identification," and the necessity to disrupt such tendencies through "forcible reminder[s] of difference" between our own experiences and those of others, in order to engage in ethical solidarity (171, 186-87). 


\section{WORKS CITED}

Alarcón, Alicia. La Migra me hizo los mandados. Houston: Arte Público, 2002. Print. . The Border Patrol Ate My Dust. Trans. Ethriam Cash Brammer. Houston: Arte Público, 2004. Print.

Bacon, David. Illegal People: How Globalization Creates Migration and Criminalizes Immigrants. Boston: Beacon, 2008. Print.

Bakhtin, Mikhail. "Author and Hero in Aesthetic Activity." Art and Answerability. Ed. Michael Holquist and Vadim Liapunov. Trans. Vadim Liapunov. Austin: U of Texas P, 1990. 4-256. Print.

Beverley, John. Testimonio: On the Politics of Truth. Minneapolis: U of Minnesota P, 2004. Print.

Caminero-Santangelo, Marta. "The Lost Ones: Post-Gatekeeper Border Fiction and the Construction of Cultural Trauma." Latino Studies 8.3 (2010): 304-327. Print.

Coutin, Susan Bibler. "The Oppressed, the Suspect, and the Citizen: Subjectivity in Competing Accounts of Political Violence." Law and Social Inquiry 26.1 (Winter 2001): 63-94. Print.

Cunningham, Hilary. "The Ethnography of Transnational Social Activism: Understanding the Global as Local Practice.” American Ethnologist 26.3 (Aug. 1999): 583-604. Print.

Das Gupta, Monisha. Unruly Immigrants: Rights, Activism, and Transnational South Asian Politics in the United States. Durham: Duke UP, 2006. Print.

Dawes, James. That the World May Know: Bearing Witness to Atrocity. Cambridge: Harvard UP, 2007. Print.

De Genova, Nicholas. “The Legal Production of Mexican/Migrant 'Illegality.'” Latino Studies 2 (2004): 160-85. Print.

Fraser, Nancy. Scales of Justice: Reimagining Political Space in a Globalizing World. New York: Columbia UP, 2009. Print.

Gidley, Ruth. "Breaking the Silence: A New Project Led by Dave Eggers is Documenting the Stories of People Whose Voices Usually Go Unheard, Finds Ruth Gidley." The Guardian [UK] 24 June 2008. Web. 12 Dec. 2011.

Hamilton, Nora, and Norma Stoltz Chinchilla. Seeking Community in a Global City: Guatemalans and Salvadorans in Los Angeles. Philadelphia: Temple UP, 2001. Print.

Hunt, Lynn. Inventing Human Rights: A History. New York: Norton, 2007. Print.

Joiner, Whitney. "Not Quite Americans." [Interview with Peter Orner.] Salon 11 June 2008. Web. 14 Dec. 2011.

Kaplan, E. Ann. Trauma Culture: The Politics of Terror and Loss in Media and Literature. New Brunswick: Rutgers UP, 2005. Print.

Lima, Lázaro. The Latino Body: Crisis Identities in American Literary and Cultural Memory. New York: New York UP, 2007. Print.

Madera, Gabriela et al., eds. Underground Undergrads: UCLA Undocumented Immigrant Students Speak Out. Los Angeles: UCLA Center for Labor Research and Education, 2008. Print. 
Moyn, Samuel. The Last Utopia: Human Rights in History. Cambridge: Belknap/Harvard UP, 2010. Print.

Nance, Kimberly A. Can Literature Promote Justice? Trauma Narrative and Social Action in Latin American Testimonio. Nashville: Vanderbilt UP, 2006. Print.

Ngai, Mae M. Impossible Subjects: Illegal Aliens and the Making of Modern America. Princeton: Princeton UP, 2004. Print.

Nyers, Peter. "Abject Cosmopolitanism: The Politics of Protection in the Anti-Deportation Movement." The Deportation Regime: Sovereignty, Space, and the Freedom of Movement. Ed. Nicholas De Genova and Nathalie Peutz. Durham: Duke UP, 2010. 413-441. Print.

Orner, Peter, ed. and comp. Underground America: Narratives of Undocumented Lives. Voice of Witness ser. San Francisco: McSweeney's Books, 2008. Print.

Peutz, Nathalie, and Nicholas De Genova. Introduction. The Deportation Regime: Sovereignty, Space, and the Freedom of Movement. Ed. Nicholas De Genova and Nathalie Peutz. Durham: Duke UP, 2010. 1-29. Print.

Portes, Alejandro. "Global Villagers: The Rise of Transnational Communities." The American Prospect (Mar.-Apr. 1996): 74-77. Print.

Schaffer, Kay, and Sidonie Smith. Human Rights and Narrated Lives: The Ethics of Recognition. New York: Palgrave Macmillan, 2004. Print.

Segreto, Joy, April Carter, and Ann Morse. "2011 Immigration-Related Laws and Resolutions in the States (January-June)." National Conference of State Legislatures. 19 Sept. 2011. Web. 10 Dec. 2011.

Sklodowska, Elzbieta. "La forma testimonial y la novelística de Miguel Barnet." Revistal Review Interamericana 12.3 (1982). 375-84. Print.

Sommer, Doris. "No Secrets." The Real Thing: Testimonial Discourse and Latin America. Ed. Georg M. Gugelberger. Durham: Duke UP, 1996. 130-57. Print.

_. "Taking a Life: Hot Pursuit and Cold Rewards in a Mexican Testimonial Novel." Signs 20.4 (1995): 913-40. Print.

Spivak, Gayatri Chakravorty. "Can the Subaltern Speak?" Marxism and the Interpretation of Culture. Ed. Cary Nelson and Lawrence Grossberg. Urbana: U of Illinois P, 1988. 271-313. Print.

Todorov, Tzvetan. The Conquest of America: The Question of the Other. Trans. Richard Howard. 1984. New York: Harper Perennial, 1992. Print.

Urrea, Luis Alberto. "Foreword: All Stories Are Refugees from Dangerous Lands." Orner $1-4$.

Westerman, William. "Central American Refugee Testimonies and Performed Life Histories in the Sanctuary Movement." The Oral History Reader. Ed. Robert Perks and Alistair Thomson. New York: Routledge, 1998. 224-34. Print.

Whitlock, Gillian, and Kate Douglas. "Located Subjects." Teaching Life Writing Texts. Ed. Miriam Fuchs and Craig Howes. New York: Modern Language Association of America, 2008. 214-20. Print.

Wyatt, Jean. Risking Difference: Identification, Race, and Community in Contemporary Fiction and Feminism. Albany: State U of New York P, 2004. Print. 